$\sim$ Amira Sami Ahmed

\title{
Influence of Relationship Marketing Underpinnings on Egyptian Hotel Customer's Satisfaction and Loyalty
}

\section{Amira Sami Ahmed}

\section{Abstract :}

Purpose - The study seeks to examine the influence of service provider's attributes on relationship marketing underpinnings, which in turn result in customer's satisfaction and loyalty towards the hotel.

Design/methodology/approach - A conceptual model linking service provider's attributes to relationship marketing underpinnings and the latter to exchange outcomes defined as customer's satisfaction and loyalty, was tested using structural equation modeling (SEM) on a sample of 279 hotel customers in Sharm El-Sheikh, Egypt.

Findings - The results showed that service provider's competency significantly influence relationship marketing underpinnings. On the other hand, the influence of service provider's appearance on customer's perception of commitment and conflict was not supported. Further, relationship marketing underpinnings significantly influence customer's satisfaction. Finally, customer's satisfaction significantly influencescustomer'sloyalty towards the hotel.

Implications - The empirical evidence of the association between service provider's attributes, relationship marketing underpinnings, customer's satisfaction, and loyalty contributes to relationship marketing literature. 
Influence of Relationship Marketing Underpinnings on Egyptian

Amira Sami Ahmed

Introduction

The study and practice of relationship marketing has experienced explosive growth over the past two decades. Companies need to move from short-term transaction goals to long-term relational goals - movement from a focus on exchanges and transactions towards a focus on value laden relationships and networks (Grönroos, 1994).

By moving from transactional discrete exchanges towards relational exchanges, benefits can be gained by both buyers and sellers (Berry, 1995). For buyers, relationships can help them reduce risk and/or transaction costs (Crosby et al., 1990; Berry, 1995; Bejouet al., 1998). For sellers, relationships can help them reduce defections and create loyalty which in turn have positive influence on firm's profitability (Reichheld and Sasser, 1990). Indeed, hoteliers are seeking ways to build long-term relationships with customers and to understand the factors that influence loyalty, in order to survive in the competitive nature of the hotel industry (Kandampully and Suhartanto, 2000).

Although relationship marketing literature has grown over the recent years, little has explored the multidimensional nature of relationship marketing in the hotel industry. Moreover, it is no surprise that most of the studies and work done on relationship marketing focused on the Western perspectives and several researchers suggest replicating their studies in different cultures. Being culturally collectivist (Ndubisi, 2004), a study on 
Influence of Relationship Marketing Underpinnings on Egyptian

Amira Sami Ahmed

relationship marketing is necessary, as different implications may be unveiled and assist managers in designing effective relationship marketing and customer's loyalty strategies.

Bitner (1995) has demonstrated that whenever a customer interacts with a service provider either by phone, email, or in person, a service encounter occurs, which contributes to customer's satisfaction and loyalty. The service provider or the salesperson is the primary if not the sole contact point of the customer - the salesperson is the company (Crosby, et al., 1990), whose characteristics and behaviors can have considerable impact on the outcome of the interactions with customers (Guenzi and Pelloni, 2004). However, little effort has been made to examine how hotel service provider's attributes as perceived by customers influence relationship marketing underpinnings to gain customer's satisfaction and loyalty.

Although keeping customers satisfied is important, loyal customers are more valuable (Bowen and Shoemaker, 1998). Therefore, customer's loyalty has been explained as a fundamental goal of firms to be attained. Reichheld and Sasser (1990) found that companies can increase profits by almost $100 \%$ by retaining only $5 \%$ more of their customers. They concluded that building relationships with customers might be of strategic focus for most service firms. Customer's loyalty is particularly vital to the hotel industry because loyal customers help promote the hotel by providing positive word-of-mouth, 
Influence of Relationship Marketing Underpinnings on Egyptian

Amira Sami Ahmed

increase sales, reduce operational costs, and sometimes serve as an information source to other customers by acting as part time employees (Bowen and Shoemaker, 1998; Bowen and Chen, 2001).

Although an extensive and thorough body of literature exists on customer's satisfaction and loyalty (e.g. Bowen and Shoemaker, 1998; Bowen and Chen, 2001; Skogland and Sigaw, 2004; Bielen and Demoulin, 2007; Namkung and Jang, 2009; Nam and Lee, 2011), past studies have reported mixed results regarding the relationship between customer's satisfaction and loyalty and multiple views exist on the conceptualization of customer's loyalty.

As such, the purpose of this study is to explore the influence of service provider's attributes on relationship marketing underpinnings, which in turn influence exchange outcomes defined as customer's satisfaction and loyalty within the Egyptian hotel industry. Specifically, examine the influence of service provider's attributes namely: expertise, experience, and physical appearance on relationship marketing underpinnings. Second, determine the influence of relationship marketing underpinnings namely: communication, trust, commitment, and conflict on customer's satisfaction and loyalty. Finally, explore the association between customer's satisfaction and loyalty.

The paper is organized as follows. First, the conceptual framework and research hypotheses are presented. Further, the methodology used to test the proposed model is explained, 
Influence of Relationship Marketing Underpinnings on Egyptian

Amira Sami Ahmed

followed by a presentation of the results of data analysis. Finally, a discussion of the study findings and implications is considered.

\section{Conceptual framework and hypotheses development}

Figure 1 depicts the proposed conceptual framework. First, this study examines the influence of three service provider attributes identified by Kim and Cha (2002) as: expertise, experience, and physical appearance, on relationship marketing underpinnings.

As for relationship marketing underpinnings, previous researchers suggested trust and commitment (Morgan and Hunt, 1994; Henning-Thurau et al., 2002; Wong and Sohal, 2002). Communication is also regarded as an important underpinning of relationship marketing (Ndubisi, 2004; Sin et al., 2005; Ndubisi, 2007).

Despite the functional benefits of conflict, only few studies added the concept of conflict to relationship marketing underpinnings. Hence, relationship marketing in this study is measured through customer's perception of four underpinnings namely: communication, trust, commitment, and conflict.

As understanding the formation of customer's loyalty remains a crucial management issue (Guenzi and Georges, 2010), the study focuses on customer's satisfaction and loyalty as outcomes to relationship marketing. 
Influence of Relationship Marketing Underpinnings on Egyptian

Amira Sami Ahmed

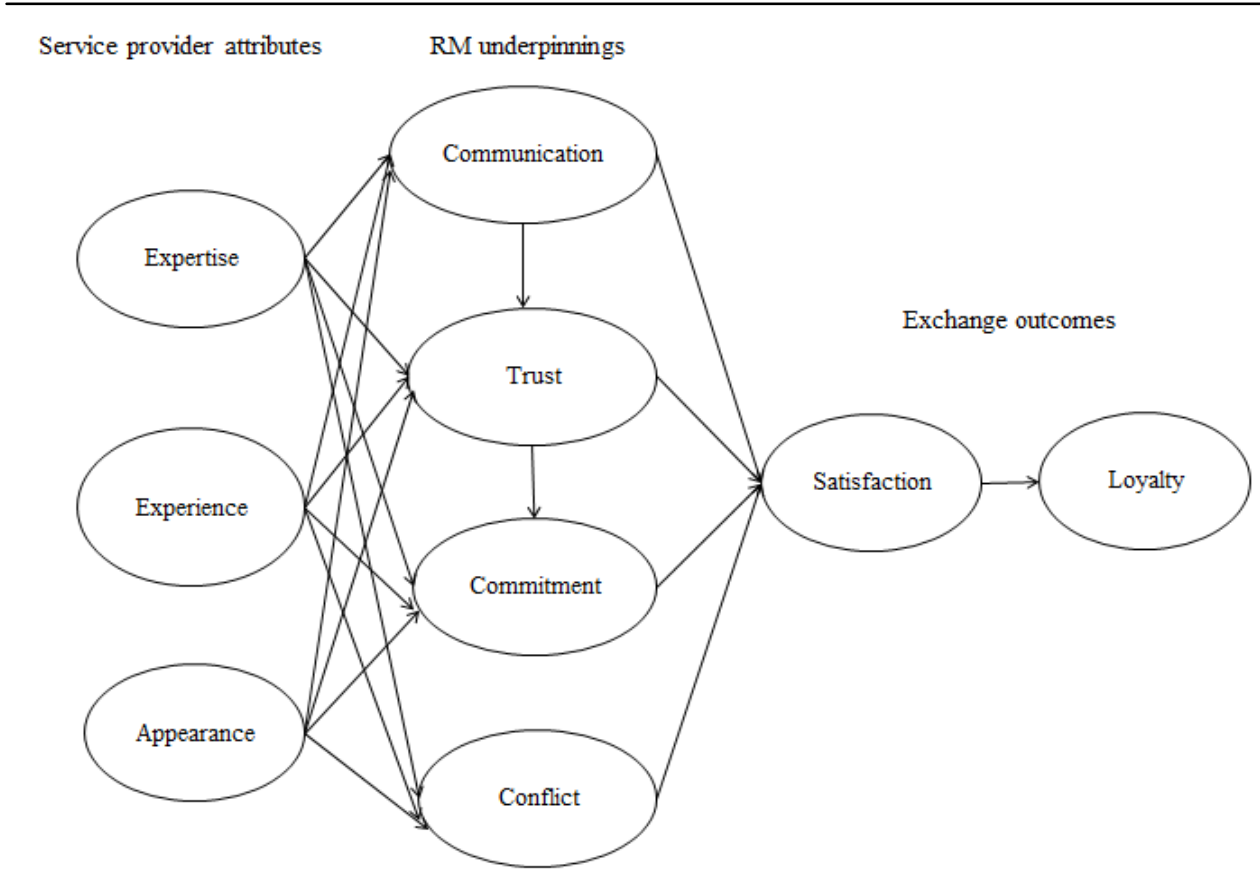

Figure 1 Proposed Conceptual Framework

Service provider attributes and relationship marketing underpinnings

Investigations into the effect of service provider's attributes on relationship marketing underpinnings have demonstrated that it is the most important antecedent of trust and satisfaction (Kim and Cha, 2002; Castellanos-Verdugo et al., 2009; Guenzi and Georges, 2010). In the context of the financial service industry, Bejouet al. (1998) showed that service provider's knowledge contributed significantly towards customer's perception of relationship satisfaction. Research has also found that expertise encourages trust (Crosbyet al., 1990; Moorman et al., 1993; Macintosh, 2007). Moreover, Söderlund 
Influence of Relationship Marketing Underpinnings on Egyptian

Amira Sami Ahmed

and Julander (2009) showed that service provider's attractiveness had a significant impact on customer's satisfaction in the bookstore and airline settings.

With this in mind, it becomes apparent that there is a need to consider the impact of service provider attributes on relationship marketing underpinnings since previous studies either investigated single attribute (e.g. expertise) or link aggregate measures of service provider's attributes to one relationship marketing underpinning (e.g. trust). Therefore:

$\mathrm{H} 1$ : Communication is a function of service provider attributes namely: a) expertise; b) experience; and c) appearance.

$\mathrm{H} 2$ : Trust is a function of service provider attributes namely: a) expertise; b) experience; and c) appearance.

H3: Commitment is a function of service provider attributes namely: a) expertise; b) experience; and c) appearance.

H4: Conflict is a function of service provider attributes namely: a) expertise; b) experience; and c) appearance.

\section{Relationship marketing underpinnings and customer's satisfaction}

Previous research provided evidence that relationship marketing had pronounced effect on customer's satisfaction and loyalty. For example, relationship marketing underpinnings of trust, commitment, and communication help service organizations gain privileged information about customer's 
Influence of Relationship Marketing Underpinnings on Egyptian

Amira Sami Ahmed

needs, and thus serve them satisfactorily (Ndubisi and Wah, 2005). Further, relationship trust and commitment are proved to impact importers of Thai products satisfaction (Terawatanavong et al., 2007). Trust and commitment are also found to impact relationship quality at a large chain departmental store in Australia (Wong and Sohal, 2002). Moreover, fostering loyalty requires banks to be trustworthy, committed to the service, reliable, and able to handle conflicts well (Ndubisi, 2006, 2007).

As can be seen, dearth of literature has been conducted to examine the direct link between relationship marketing underpinnings and customer's satisfaction. In addition, studies on relationship marketing multidimensional nature have been restricted to service organizations such as banks, retailers, and other settings, as hardly any work has been done in the hotel industry. Indeed:

H5: Satisfaction is a function of relationship marketing underpinnings namely: a) communication; b) trust; c) commitment; and d) conflict.

Morgan and Hunt (1994) demonstrated that trust and commitment are important constructs for measuring customer's loyalty and likelihood to repurchase. Past studies have showed that communication is a keyantecedent of trust (e.g. Morgan and Hunt, 1994; Ndubisi et al., 2007). In 
Influence of Relationship Marketing Underpinnings on Egyptian

Amira Sami Ahmed

addition, trust correlates positively with commitment (Morgan and Hunt, 1994; Wong and Sohal, 2002; Cater and Zabkar, 2009). Despite the interrelationships among relationship marketing underpinnings, that in turn will impact exchange outcomes, only few studies have examined the influence of relationship marketing underpinnings on one another. Thus:

H6: Trust is a function of communication.

H7: Commitment is a function of trust.

\section{Customer's satisfaction and loyalty}

Several studies have been conducted to explore the relationship between customer's satisfaction and loyalty. For instance, satisfaction with a hotel is directly related to repurchase as well as positive word-of-mouth communication intentions (Oh, 1999). Similarly, customer's overall satisfaction levels positively influence their likelihood of returning to the same hotel (Choi and Chu, 2001). Further, interpersonal relationships are found to impact customer's satisfaction and loyalty in the retail context (Guenzi and Pelloni, 2004; Vesel and Zabkar, 2009; Adjei and Clark, 2010). In recent years, researchers empirically validated the association between customer's satisfaction and loyalty in restaurants (Namkung and Jang, 2009; Nam and Lee, 2011; Ryu and Han, 2011). Moreover, the effect of visitor's satisfaction attending a festival has been described as a predictor of loyalty (Kim et al., 2010; Yoon et al., 2010). 
Influence of Relationship Marketing Underpinnings on Egyptian

Amira Sami Ahmed

By contrast, Skogland Sigaw (2004) claimed that customer's satisfaction does not have the substantive influence on loyalty that has previously been assumed. Bowen and shoemaker (1998) indicated that travelers who do not regularly visit a particular area cannot be loyal to a property because they will never return to the area. In addition, some luxury hotel guests seek variety and visit a different property each time they return to an area.

Despite the multifaceted nature of customer's loyalty, previous studies have not captured the full range of potential loyalty reactions that may follow a service encounter. For example, Guenzi and Pelloni (2004) focused solely on repatronage behavior and measured the construct with a single item scale. Furthermore, in Oh (1999) and Bowen and Chen (2001) studies, purchase intentions and willingness to recommend were the only two dimensions used.

Given the lack of consensus in this area, the relationship between hotel customer's satisfaction and loyalty and the conceptualization of customer's loyalty remain unclear and challenging. As such:

H8: Loyalty is a function of satisfaction.

\section{Research methodology}

\section{Measures}

The researcher selected measures for the model constructs from previous studies which were found reliable and valid. Specifically, Kim and Cha (2002) scale is used for expertise (3 items), experience (3 items), and physical appearance (3 items). 
Influence of Relationship Marketing Underpinnings on Egyptian

Amira Sami Ahmed

To measure communication, three items are adapted from Ndubisi (2007). To measure trust, five items are adapted from Crosbyet al. (1990), Morgan and Hunt (1994), and Gwinneret al. (1998). Commitment is assessed using five items adapted from Moormanet al., (1992), Morgan and Hunt (1994), and Wong and Sohal (2002). To measure conflict, three items are utilized from Roberts et al. (2003). Four items are determined from HenningThurauet al., (2002) to measure satisfaction. Finally, customer's loyalty is measured based on Bloemeret al., (1999) 13 items battery. All items are rated on a five point Likert scale (1= strongly disagree to $5=$ strongly agree).

\section{Sample}

A stratified random sampling approach based upon the star rating system (five and four star hotels), is adopted. The appropriate sample size is based on the number of five and four star hotel rooms' capacity in Sharm El-Sheikh, which is 40818 rooms (Egyptian Hotel Association, 2011).

According to Sekaran (2010), if the number of population to be sampled is more than 40,000, the sample size should be 380. This sample size is proportionally distributed according to the number of hotel rooms' capacity in each star category, as in table 1 .

\section{Table 1}


Influence of Relationship Marketing Underpinnings on Egyptian

Amira Sami Ahmed

Devising a stratified random sample - room's capacity

\begin{tabular}{|c|c|c|c|}
\hline Hotel category & $\begin{array}{c}\text { Hotel rooms' } \\
\text { capacity } \\
N\end{array}$ & Percent & $\begin{array}{c}\text { Sample size } \\
\boldsymbol{n}\end{array}$ \\
\hline Five star hotels & $\mathbf{2 1 0 6 3}$ & $\mathbf{5 1 . 6 \%}$ & 169 \\
Four star hotels & 19755 & $\mathbf{4 8 . 4 \%}$ & 184 \\
\hline Total & $\mathbf{4 0 8 1 8}$ & $\mathbf{1 0 0 \%}$ & $\mathbf{3 8 0}$ \\
\hline
\end{tabular}

Source: Egyptian Hotel Association (2011)

\section{Data collection process}

The researcher approaches five and four star hotels in Sharm El-Sheikh via telephone, outlines the purpose of the study, and invites them to participate in the survey. The questionnaires are distributed to each selected guest room with the help of hotel's reception desk employees and security staff. A total of 380 customers received the questionnaire with a cover letter on university letterhead explaining the purpose of the study, ensuring confidentiality, and encouraging subjects to participate. The hotel's front desk management assist in assuring that the subjects had stayed at the hotel at least one night before they received the questionnaire. Subjects are allowed to return their surveys to the hotel's lobby reception desk.Of the total 380 customers selected, 329 responded to the questionnaire. After dropping incomplete questionnaires, 279 were valid for data analysis representing $72.6 \%$ response rate.

\section{Data analysis procedures}


Influence of Relationship Marketing Underpinnings on Egyptian

Amira Sami Ahmed

Exploratory factor analysis is first conducted to identify the underlying dimensions of service provider's attributes, relationship marketing underpinnings, customer's satisfaction, and loyalty. Reliabilities of all constructs are tested using Cronbach's alpha. Confirmatory factor analysis (CFA) is followed to examine convergent and discriminant validity. Finally, structural equation modeling (SEM) using AMOS 18.0 is used to test the research hypotheses.

\section{Data analysis and results}

\section{Exploratory factor analysis}

An exploratory factor analysis with principal component extraction and Varimax rotation was performed to assess the dimensions of all the model constructs. Those items with communalities less than 0.50 , items with high cross loadings, or factor loadings less than 0.40 should be removed (Hair et al., 2010).

Based on the results uncovered in the exploratory factor analysis, a revised model of the hypothesized relationships is presented in figure 2. The analysis has proven that service provider's attributes pertained to two dimensions: competency and physical appearance. Also, relationship marketing four underpinnings did not hold up in the Egyptian hotel context, instead three factors were revealed: assurance, commitment, and conflict. Therefore, the following research hypotheses were formulated: 
Influence of Relationship Marketing Underpinnings on Egyptian

Amira Sami Ahmed

$\mathrm{H} 1$ : Assurance is a function of service provider attributes namely: a) competency; b) appearance.

$\mathrm{H} 2$ : Commitment is a function of service provider attributes namely: a) competency; b) appearance.

H3: Conflict is a function of service provider attributes namely:

a) competency; b) appearance.

H4: Satisfaction is a function of relationship marketing underpinnings namely: a) assurance; b) commitment; and c) conflict.

H5: Loyalty is a function of satisfaction.

\section{Reliability and validity}

Cronbach's alpha was utilized to measure the internal consistency of the measurement items (see table 2). The alpha values ranged from 0.70 to 0.92 , exceeding the threshold of 0.70 specified by Hair et al. (2010).

Confirmatory factor analysis (CFA) was conducted to assess the construct validity of the measurement items. Construct validity was examined through convergent and discriminant validity (Hair et al., 2010). 
Influence of Relationship Marketing Underpinnings on Egyptian

Amira Sami Ahmed

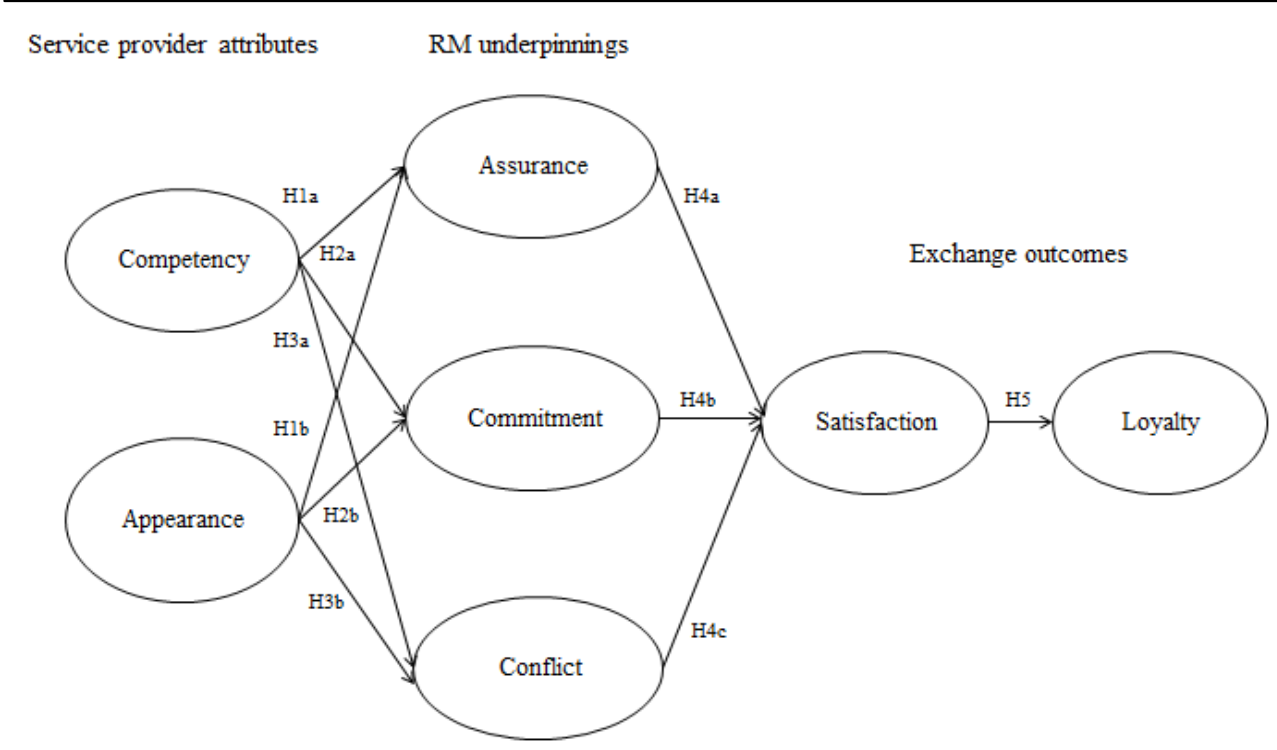

Figure 2 Revised conceptual framework

To estimate convergent validity among measurement items, the standardized loadings should exceed 0.50 and be statistically significant. Also, average variance extracted (AVE) of 0.50 or higher is a good rule of thumb suggesting adequate convergence (Hair et al., 2010). All loadings were above 0.50 except for loyalty items $9,10,11$, and 12 , which fell significantly below the desired 0.50 threshold (see table 2). Average variance extracted of loyalty falls below the threshold of 0.50 , another indicator of perhaps improvement of the construct by eliminating items with low convergence. Therefore, they become prime candidates of deletion. Another two items from loyalty (item 7 and 8) fell below the suggested level, but were close to 0.50. As the principal component analysis results showed that these items 
Influence of Relationship Marketing Underpinnings on Egyptian

Amira Sami Ahmed

did load on a single factor, it was decided not to eliminate these items based on content validity considerations.

\section{Table 2}

Confirmatory factor analysis and reliability of the measurement items

\begin{tabular}{|c|c|c|c|}
\hline Construct/item & $\begin{array}{l}\text { Standardized } \\
\text { Loading }\end{array}$ & AVE & $\begin{array}{c}\text { Cronbach's } \\
\alpha\end{array}$ \\
\hline $\begin{array}{l}\text { Competency: } \\
\text { 1. Employees have } \\
\text { professional training and } \\
\text { education. } \\
\text { 2. Employees demonstrate } \\
\text { adequate knowledge } \\
\text { about the hotel product } \\
\text { and service. }\end{array}$ & $\begin{array}{l}0.763 \\
0.812 \\
0.846 \\
0.847 \\
0.815 \\
0.721\end{array}$ & 0.643 & 0.91 \\
\hline $\begin{array}{l}\text { Physical appearance: } \\
\text { 1. Employee's appearance is } \\
\text { professional. } \\
\text { 2. Employees are well } \\
\text { dressed. } \\
\text { 3. Employees have a nice } \\
\text { manner. }\end{array}$ & $\begin{array}{l}0.881 \\
0.884 \\
0.760\end{array}$ & 0.712 & 0.87 \\
\hline
\end{tabular}


Influence of Relationship Marketing Underpinnings on Egyptian

Amira Sami Ahmed

\begin{tabular}{|c|c|c|c|}
\hline $\begin{array}{l}\text { Assurance: } \\
\text { 1. Employees provide timely } \\
\text { and trustworthy } \\
\text { information. }\end{array}$ & 0.767 & 0.550 & 0.89 \\
\hline Construct/item & $\begin{array}{c}\text { Standardized } \\
\text { Loading }\end{array}$ & AVE & $\begin{array}{c}\text { Cronbach's } \\
\alpha\end{array}$ \\
\hline $\begin{array}{l}\text { 2. Employees provide } \\
\text { information when there } \\
\text { are new services. } \\
\text { 3. Information provided by } \\
\text { employees is always } \\
\text { accurate. } \\
\text { 4. I know what to expect } \\
\text { when I go in. } \\
\text { 5. Employees can be trusted } \\
\text { completely. } \\
\text { 6. Employees have high } \\
\text { integrity. } \\
\text { 7. Employees can be relied } \\
\text { upon to keep promises. }\end{array}$ & $\begin{array}{l}0.633 \\
0.734 \\
0.686 \\
0.801 \\
0.809 \\
0.743\end{array}$ & & \\
\hline $\begin{array}{l}\text { Commitment: } \\
\text { 1. I am very committed to } \\
\text { the relationship with } \\
\text { employees. } \\
\text { 2. I really care about the } \\
\text { relationship with } \\
\text { employees. } \\
\text { 3. The relationship deserves } \\
\text { my maximum effort to } \\
\text { maintain. } \\
\text { 4. The relationship is very } \\
\text { important to me. } \\
\text { 5. I intend to maintain the } \\
\text { relationship in the long- } \\
\text { term. }\end{array}$ & $\begin{array}{l}0.786 \\
0.838 \\
0.658 \\
0.829 \\
0.630\end{array}$ & 0.567 & 0.85 \\
\hline
\end{tabular}


Influence of Relationship Marketing Underpinnings on Egyptian

Amira Sami Ahmed

\begin{tabular}{|c|c|c|c|}
\hline $\begin{array}{l}\text { Conflict: } \\
\text { 1. I am angry with } \\
\text { employees. } \\
\text { 2. I am frustrated with } \\
\text { employees. }\end{array}$ & $\begin{array}{l}0.858 \\
0.888\end{array}$ & 0.750 & 0.90 \\
\hline Construct/item & $\begin{array}{l}\text { Standardized } \\
\text { Loading }\end{array}$ & AVE & $\begin{array}{c}\text { Cronbach's } \\
\alpha\end{array}$ \\
\hline $\begin{array}{l}\text { 3. I am annoyed with } \\
\text { employees. }\end{array}$ & 0.852 & & \\
\hline $\begin{array}{l}\text { Satisfaction: } \\
\text { 1. My choice to use this } \\
\text { hotel was a wise one. } \\
\text { 2. I am always delighted } \\
\text { with this hotel. } \\
\text { 3. Overall, I am satisfied } \\
\text { with this hotel. } \\
\text { 4. I think I did the right } \\
\text { thing when I decided to } \\
\text { use this hotel. }\end{array}$ & $\begin{array}{l}0.786 \\
0.821 \\
0.909 \\
0.840\end{array}$ & 0.737 & 0.92 \\
\hline $\begin{array}{l}\text { Loyalty: } \\
\text { Loyalty to hotel } \\
\text { 1. I say positive things about } \\
\text { this hotel to other people. } \\
\text { 2. I would recommend this } \\
\text { hotel to someone who } \\
\text { seeks my advice. } \\
\text { 3. I would encourage friends } \\
\text { and relatives to visit this } \\
\text { hotel. } \\
\text { 4. I consider this hotel my } \\
\text { first choice to visit. } \\
\text { 5. I would do more business } \\
\text { with this hotel in the next } \\
\text { few years. } \\
\text { 6. I would do less business } \\
\text { with this hotel in the next }\end{array}$ & $\begin{array}{l}0.919 \\
0.937 \\
0.865 \\
0.778 \\
0.779 \\
0.645\end{array}$ & 0.376 & 0.70 \\
\hline
\end{tabular}


Influence of Relationship Marketing Underpinnings on Egyptian

Amira Sami Ahmed

\begin{tabular}{|c|c|c|c|}
\hline few years (Reversed). & & & \\
\hline Construct/item & $\begin{array}{l}\text { Standardized } \\
\text { Loading }\end{array}$ & AVE & $\begin{array}{c}\text { Cronbach's } \\
\alpha \\
\end{array}$ \\
\hline $\begin{array}{l}\text { Propensity to switch } \\
\text { 7. I would switch to a } \\
\text { competitor that offers } \\
\text { better price. } \\
\text { Willingness to pay more } \\
\text { 8. I would continue to visit } \\
\text { this even if its prices } \\
\text { increased somewhat. } \\
\text { 9. I would pay higher price } \\
\text { than competitors charge } \\
\text { for the benefits I } \\
\text { currently receive from } \\
\text { the hotel. } \\
\text { Complaining behavior } \\
\text { 10. I would complain to other } \\
\text { consumers if I experience } \\
\text { a problem with this hotel. } \\
\text { 11. I would complain to } \\
\text { external agencies if I } \\
\text { experience a problem } \\
\text { with this hotel. } \\
\text { 12. I would complain to } \\
\text { employees if I experience } \\
\text { a problem with this hotel. }\end{array}$ & $\begin{array}{l}0.300 \\
0.450 \\
0.112 \\
-0.200 \\
-0.267 \\
0.067\end{array}$ & & \\
\hline
\end{tabular}

Note: All loadings are significant at $p<0.001$. AVE $=$ average variance extracted.

Discriminant validity was assessed by comparing the AVE of any two constructs with the square of the correlation estimate between these constructs. The variance extracted estimates should be greater than the squared correlations (Hair et al., 
Influence of Relationship Marketing Underpinnings on Egyptian

Amira Sami Ahmed

2010). All AVE estimates are greater than the corresponding interconstruct squared correlation estimates except for satisfaction and loyalty (see table 3).

Accordingly, a fit comparison of nested models was performed. Model with correlation between the two factors constrained to 1.00 was compared to a model where the two factors were free to correlate. A significant lower Chi-square $\left(x^{2}\right)$ value for the unconstrained model supports discriminant validity (Hair et al., 2010). Since the difference in Chi-square was statistically significant $\left(x^{2}=7.553,1, p<0.05\right)$, the existence of discriminant validity was inferred.

Table 3 Constructs correlation matrix (Standardized)

\begin{tabular}{|llllllll|}
\hline Construct & 1 & 2 & 3 & 4 & 5 & 6 & 7 \\
\hline 1. Competency & $\mathbf{0 . 6 4 3}$ & $\mathbf{0 . 4 8 9}$ & $\mathbf{0 . 4 7 6}$ & $\mathbf{0 . 1 9 3}$ & $\mathbf{0 . 1 4 7}$ & $\mathbf{0 . 2 9 7}$ & $\mathbf{0 . 2 4 4}$ \\
2. Appearance & $\mathbf{0 . 6 9 9}$ & $\mathbf{0 . 7 1 2}$ & $\mathbf{0 . 5 4 4}$ & $\mathbf{0 . 0 9 9}$ & $\mathbf{0 . 1 1 6}$ & $\mathbf{0 . 3 0 9}$ & $\mathbf{0 . 3 0 1}$ \\
3. Assurance & $\mathbf{0 . 6 9 0}$ & $\mathbf{0 . 7 3 8}$ & $\mathbf{0 . 5 5 0}$ & $\mathbf{0 . 3 2 1}$ & $\mathbf{0 . 1 3 2}$ & $\mathbf{0 . 4 0 1}$ & $\mathbf{0 . 4 4 3}$ \\
4. Commitment & $\mathbf{0 . 4 3 9}$ & $\mathbf{0 . 3 1 4}$ & $\mathbf{0 . 5 6 7}$ & $\mathbf{0 . 5 6 7}$ & $\mathbf{0 . 0 5 5}$ & $\mathbf{0 . 2 8 5}$ & $\mathbf{0 . 2 6 6}$ \\
5. Conflict & - & - & - & - & $\mathbf{0 . 7 5 0}$ & $\mathbf{0 . 1 4 6}$ & $\mathbf{0 . 1 5 4}$ \\
6. Satisfaction & $\mathbf{0 . 3 8 3}$ & $\mathbf{0 . 3 4 1}$ & $\mathbf{0 . 3 6 4}$ & $\mathbf{0 . 2 3 5}$ & - & $\mathbf{0 . 7 3 7}$ & $\mathbf{0 . 8 8 0}$ \\
7. Loyalty & $\mathbf{0 . 5 4 5}$ & $\mathbf{0 . 5 5 6}$ & $\mathbf{0 . 6 3 4}$ & $\mathbf{0 . 5 3 4}$ & $\mathbf{0 . 3 8 2}$ & $\mathbf{0 . 9 3 9}$ & $\mathbf{0 . 3 7 6}$ \\
& $\mathbf{0 . 4 9 4}$ & $\mathbf{0 . 5 4 6}$ & $\mathbf{0 . 6 6 6}$ & $\mathbf{0 . 5 1 6}$ & - & & \\
& & & & & $\mathbf{0 . 3 9 3}$ & & \\
\hline
\end{tabular}

Note: Values below the diagonal are correlation estimates, diagonal elements are AVE estimates, and values above the diagonal are squared correlations $(p<0.001)$.

\section{Structural equation modeling}


Influence of Relationship Marketing Underpinnings on Egyptian

Amira Sami Ahmed

The model revealed a significat Chi-square $\left(x^{2}=1528.199\right.$, $583, p<0.001)$, thereby suggesting that the model fit was not entirely adequate. However, Chi-square $\left(x^{2}\right)$ test is sensitive to sample size, which may lead to inaccurate results (Hair et al., 2010). Therefore, other fit indices are reported including comparative fit index (CFI), root mean square residual (RMR), and root mean square error of approximation (RMSEA).

The values of RMR and RMSEA were 0.060 and 0.076 respectively, thus fell within the desired range as suggested by Hair et al. (2010). The CFI index was slightly below the 0.90 threshold (Byrne, 2009; Hair et al., 2010). Consequently, the hypothesized model reasonably fits the sample data.

The structural paths were examined for theoretical and practical implications.

The parameter estimates should exhibit correct sign and size and be consistent with the underlying theory. Nonsignificant parameters can be considered unimportant to the model and should be deleted (Byrne, 2009).

As in table 4, the hypothesized relationships among the constructs tested in the model were mostly supported. 
Influence of Relationship Marketing Underpinnings on Egyptian

Amira Sami Ahmed

Table 4

Parameter estimates of the proposed model

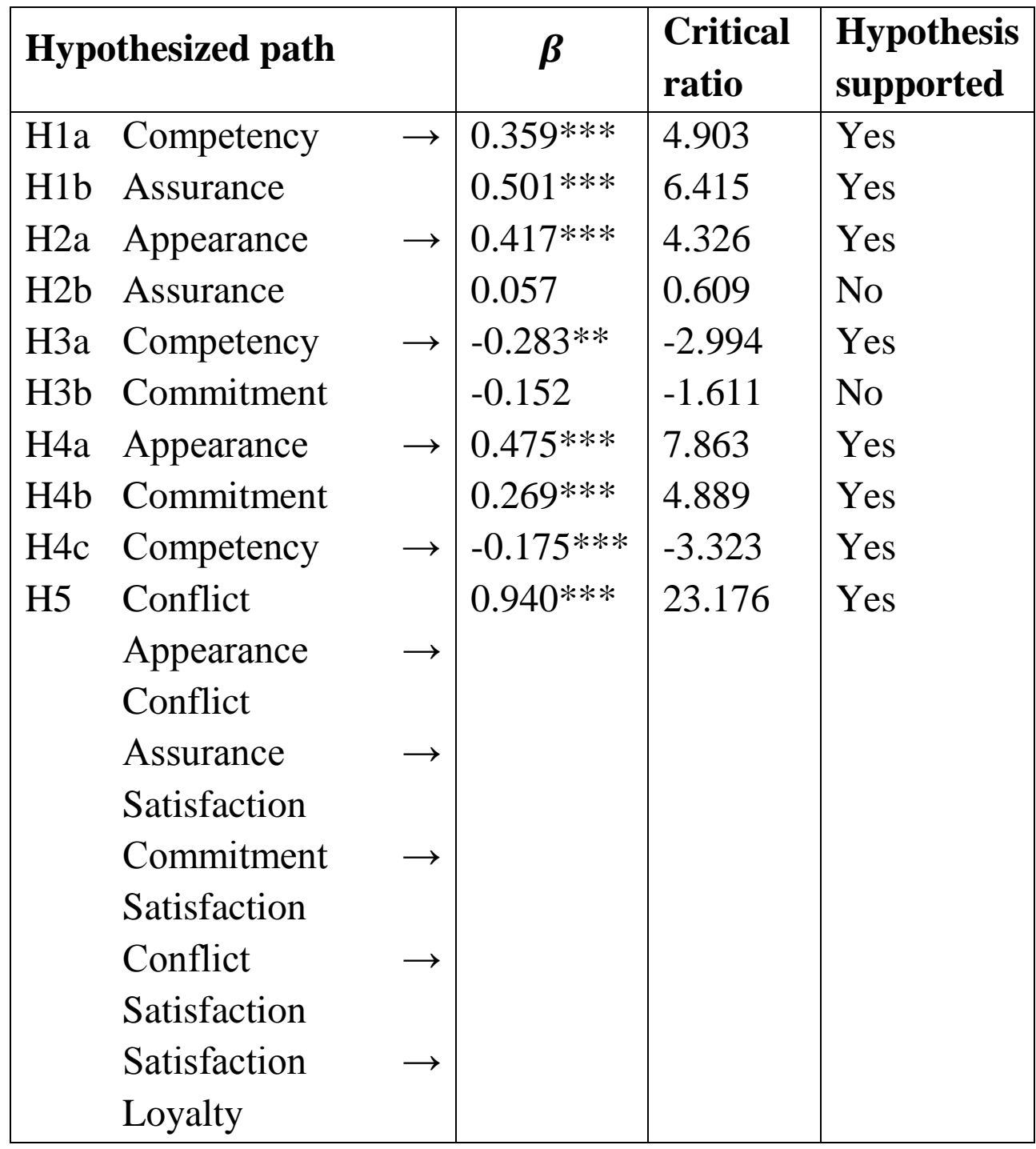

Note: Significance levels are denoted as $* * * p<0.001$, ** $p<$ 0.01 . 
Influence of Relationship Marketing Underpinnings on Egyptian

Amira Sami Ahmed

\section{Conclusion}

The study is set out to investigate the influence of service provider's attributes on relationship marketing underpinnings, which in turn influence exchange outcomes defined as customer's satisfaction and loyalty within the Egyptian hotel context. The findings revealed that service provider's competency is significantly related to relationship marketing underpinnings: assurance, commitment, and conflict. Further, service provider's appearance is significantly related to assurance. The paths linking service provider's appearance to commitment and conflict are not supported in this study. Moreover, relationship marketing underpinnings are significantly related to customer's satisfaction. Finally, the direct link between customer's satisfaction and loyalty is supported.

This study provides hotel managers with empirical evidence of the personal characteristics that service providers should adopt to influence the creation of long term relationships with customers. Managers should ensure that service providers reflect demonstrated competency in service encounters. Also, managers should examine the manner in which employees dress and determine if changes need to be made in color, design, and intensity.

To stimulate service providers to perform the desired relational behaviors, hotel managers should select and recruit candidates for positions depending on their relational skills and attributes. Managers also need to design training programs to help employees develop the skills and competencies required to 
Influence of Relationship Marketing Underpinnings on Egyptian

Amira Sami Ahmed

successfully adopt relationship marketing strategy. Such programs should also emphasize the importance of physical appearance at least during the initial encounters. Moreover, managers need to develop reward systems based on relationship marketing indicators such as customer's satisfaction and loyalty.

Further, the findings indicated that customer's satisfaction and loyalty could be achieved through relationship marketing practices. In implementing relationship marketing, hotel managers have no control over customer's preferences and inherent perspectives and some customers want long term relationships and others not, thereby the customer database should be carefully refined and segmented. The $80 / 20$ rule applies in the hotel industry - that is approximately $80 \%$ of the total revenue comes from $20 \%$ of the customers (Kim and Cha, 2002). Therefore, hotel managers should invest most of the marketing resources on $20 \%$ of the customers.

In addition, hotel managers should conduct periodic surveys to identify the overall customer profile and to segment according to their perceptions of relationship marketing underpinnings with regard to assurance, commitment, and conflict. Each segment has a different impact on hotel's profitability depending on their satisfaction and loyalty towards the hotel. Thus, each customer segment should be targeted with a specific strategy. A customer oriented strategy based on relationship marketing activities should be directed to the most profitable segment as these will eventually lead to better 
Influence of Relationship Marketing Underpinnings on Egyptian

Amira Sami Ahmed

understanding of customers' needs to gain their satisfaction and loyalty.

To sum up, most of the research hypotheses presented in this study are unvieled by the resulting analysis. Inherent to these research hypothesesis the idea that service provider's attributes contribute significantly to customer's perception of relationship marketing strategy, customer's satisfaction relies more on the trustworthy information received during service delivery, and customer's overall satisfaction is positively and significantly related to loyalty. On the other hand, the relationships of appearance with commitment and conflict are insignificant. 
Influence of Relationship Marketing Underpinnings on Egyptian

Amira Sami Ahmed

\section{References}

Adjei M. T. and Clark M. N. (2010). "Relationship marketing in a B2C context: the moderating role of personality traits". Journal of Retailing and Consumer Services, 17, 73-79.

Bejou D., Ennew C. T. and Palmer A. (1998).“Trust, ethics and relationship satisfaction”.International Journal of Bank Marketing, 16(4), 170-175.

Berry L. L. (1995). "Relationship Marketing of Services - Growing Interest, Emerging Perspectives".Journal of the Academy of Marketing Science, 23(4), 236-245.

Bielen F. and Demoulin N. (2007). "Waiting time influence on the satisfaction - loyalty relationship in services".Managing Service Quality, 17(2), 174-193.

Bitner M. J.(1995). "Building service relationships: it's all about promises". Journal of the Academy of Marketing Science, 23(3), 246-251.

Bloemer J., Rutyer K. and Wetzels M. (1999). "Linking perceived service quality and service loyalty: a multidimensional perspective". European Journal of Marketing, 33(11/12), 1082-1106.

Bowen J.T. and Chen S.L. (2001).“The relationship between customer loyalty andcustomer satisfaction”. International Journal of Contemporary Hospitality Management, 13(5), 213-217.

Bowen J. T. and Shoemaker S. (1998). "Loyalty: a strategic commitment".

Cornell Hotel and Restaurant Administration Quarterly, 12-25.

Byrne B. M. (2009). Structural equation modeling with AMOS: Basic concepts, applications, and programming. Routledge.

Castellanos-Verdugo M. C., Garcia M. O., Roldain J. L. and Veerapermal N. (2009). "The employee customer relationship quality: antecedents and consequences in the hotel industry". International Journal of Hospitality Management, 21(3), 251-274.

Cater B. and Zabkar V. (2009). "Antecedents and consequences of commitment in marketing research services: the client's perspective". Journal of Industrial Marketing Management, 38, 785-797. 
Influence of Relationship Marketing Underpinnings on Egyptian

Amira Sami Ahmed

Choi T. Y. and Chu R. (2001).“Determinants of hotel guest's satisfaction and repeat patronage in the Hong Kong hotel industry". International Journal of Hospitality Management, 20(3), 277-297.

Crosby L. A., Evans K. R. and Cowles D. (1990). "Relationship quality in service selling: an interpersonal influence perspective". Journal of Marketing, 54, 68-81.

Egyptian Hotel Association.(2011). Hotel Guide. Egypt: EHA.

Grönroos C. (1994). "From Marketing Mix to Relationship Marketing: Towards a Paradigm Shift in Marketing”. Management Decision, 32(2), 4-20.

Guenzi P. and Georges L. (2010). "Interpersonal trust in commercial relationships: antecedents and consequences of customer trust in the salesperson”. European Journal of Marketing, 44(1/2), 114-138.

Guenzi P. and Pelloni O. (2004). "The impact of interpersonal relationships on customer satisfaction and loyalty to the service provider".International Journal of Service Industry Management, 15(4), 365-384.

Gwinner K.P., Gremeler D.D. and Bitner M.J. (1998). "Relational benefits in services industries: the customer's perspective". Journal of the Academy of Marketing Science, 26(2), 101-114.

Hair Jr. J., Black W. C., Babin B. J. and Anderson R. E. (2010).Multivariate data analysis.Pearson Prentice Hall.

Henning-Thurau T., Gwinner K.P., Gremeler D.D. (2002).“Understanding relationship marketing outcomes: an integration of relational benefits and relationship quality".Journal of Service Research, 4(3), 230-247.

Kandampully J. and Suhartanto D. (2000). "Customer loyalty in the hotel industry: the role of customer satisfaction and image". International Journal of Contemporary Hospitality Management, 12(6), 346-351.

Kim W. G. and Cha Y. (2002)."Antecedents and consequences of relationship quality in hotel industry”.International Journal of Hospitality Management, 21, 321-338. 
Influence of Relationship Marketing Underpinnings on Egyptian

Amira Sami Ahmed

Kim Y. G., Suh B. W. and Evens A. (2010). "The relationship between food related personality traits, satisfaction and loyalty among visitors attending food events and festivals". International Journal of Hospitality Management, 29, 216-226.

Macintosh G. (2007). "Customer orientation, relationship quality and relational benefits to the firm".Journal of Service marketing, 21(3), 150-159.

Moorman C., Zaltman G. and Deshpande R. (1992). "Relationships between providers and users of market Research: the dynamics of trust within and between organizations". Journal of Marketing Research, 314-328.

Moorman C., Deshpande'R. and Zaltman G. (1993). "Factors affecting trust in market research relationships". Journal of Marketing, 57, 81-103.

Morgan R. M. and Hunt S. D. (1994). "The commitment-trust theory of relationship marketing".Journal of Marketing, 58, 20-38.

Nam J. H. and Lee T. J. (2011)."Foreign traveler's satisfaction with traditional Korean restaurants".International Journal of Hospitality Management, 30, 982-989.

Namkung Y. and Jang S. C. S. (2009). "The effects of interactional fairness on satisfaction and behavioral intentions: mature versus non mature customers". International Journal of hospitality management, 28, 397405.

Ndubisi N. O. (2004). "Understanding the salience of cultural dimensions on relationship marketing, it's underpinnings and aftermaths". Cross Cultural Management, 11(3), 70-89.

Ndubisi N. O. and Wah C. K. (2005). "Factorial and discriminant analysis of the underpinnings of relationship marketing and customer satisfaction". International Journal of Bank Marketing, 23(7), 542-557.

Ndubisi N. O. (2006). "Effect of gender on customer loyalty: a relationship marketing approach". Marketing Intelligence and Planning, 24(1), 4861.

Ndubisi N. O. (2007). "Relationship marketing and customer loyalty”.Marketing Intelligence and Planning, 25(1), 98-106. 
Influence of Relationship Marketing Underpinnings on Egyptian

Amira Sami Ahmed

Ndubisi N.O., Wah C.K. and Ndubisi G. C. (2007). "Supplier customer relationship management and customer loyalty: the banking industry perspective". Journal of Enterprise information management, 20(2), 222-236.

Oh H. (1999). "Service quality, customer satisfaction and customer value: a holistic perspective". International Journal of Hospitality Management, 18, 67-82.

Reichheld F. F. and Sasser W. E. (1990). "Zero defections: quality comes to services". Harvard Business Review, 105-111.

Roberts K., Varki S. and Brodie R. (2003)."Measuring the quality of relationships in consumer services: an empirical study".EuropeanJournal of Marketing, 17(1/2), 169-196.

Ryu K. and Han H. (2011). "New or repeat customers: how does physical environment influence their restaurant experience".International Journal of Hospitality Management, 30, 599-611.

Sekaran. (2010). Research methods for business: A skill building approach. New Jersey: John Wiley and Sons.

Sin L.Y. M., Tse A. C. B., Yau O. H. M., Chow R., Lee J. S. Y. and Lau L.B.Y. (2005). "Relationship marketing orientation: scale development and cross cultural validation". Journal of Business Research, 58, 185194.

Skogland I. and Sigaw J. A. (2004). "Are your satisfied customers loyal?".The Cornell Hotel and Restaurant Management Quarterly, 45(3), 221-234.

Söderlund M. and Julander (2009)."Physical attractiveness of service worker in moment of truth and its effects on customer satisfaction".Journal of Retailing and Consumer Services, 16, 216-226.

Sundaram D. S. and Webster C. (2000). "The role of nonverbal communication in service encounters". Journal of Service Marketing. 14(5), 378-391. 
Influence of Relationship Marketing Underpinnings on Egyptian

Amira Sami Ahmed

Terawatanavong C., Whitewell G. J. and Widing R. E. (2007)."Buyer satisfaction with relational exchange across the relationship lifecycle". European Journal of Marketing, 41(7/8), 915-938.

Vesel P. and Zabkar V. (2009)."Managing customer loyalty through the mediating role of satisfaction in the DIY retail loyalty program".Journal of Retailing and Consumer Services, 16, 396-406.

Wong A. and Sohal A. (2002).“An examination of the relationship between trust, commitment and relationship quality". International Journal of Retail and Distribution Management, 30(1), 34-50.

Yoon Y. S., Lee J. S. and Lee C. K. (2010). "Measuring festival quality and value affecting visitors satisfaction and loyalty using a structural approach". International Journal of Hospitality Management, 29, 335342. 
Influence of Relationship Marketing Underpinnings on Egyptian

$\sim$ Amira Sami Ahmed

تأثير محددات التسويـق بالعـلاقـات على رضـاء وولاء عمـلاء القتـادق المصـريـة

الكهدف:

تهدف الدر اسة بشكل أساسى الي دراسة تأثير صفات مقدمى الخدمة بالفنادق

المصرية على محددات التسويق بالعلاقات التي تعمل بمثابة سوابق لنتائج التعاملات

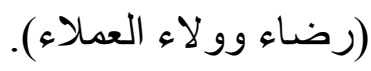

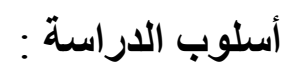

اعتمدت الدراسة على اسلوب الاستقصاء فى تجميع البيانات. تحدد حجم

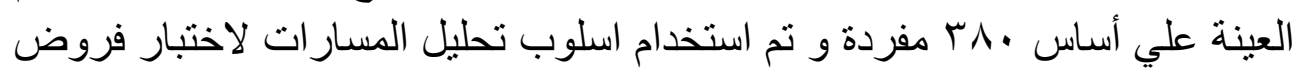
الدراسة.

النتائج :

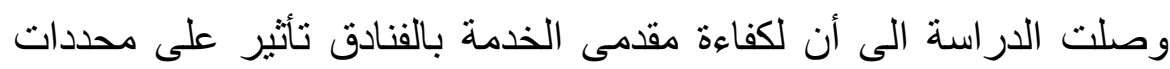

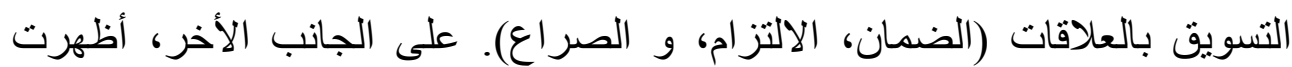

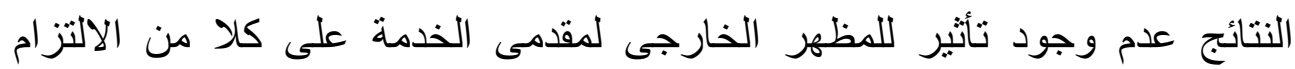
و الصراع. كما أظهرت النتائج أن لمحددات التسويق بالعلاقات تأثير على رضئ رضاء

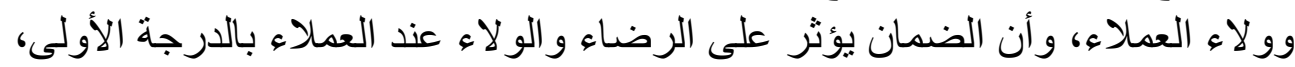

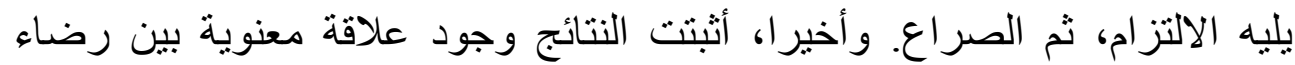
وو لاء العملاء للفندق.

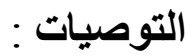

انتهت الدراسة بتقديم مجموعة من التوصيات منها أن تقوم الفنادق بتطوير

استر اتيجيات تسويقية مميزة نحو بناء علاقات طويلة الأجل مع العملاء و الحفاظ

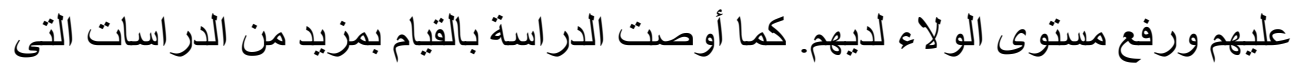

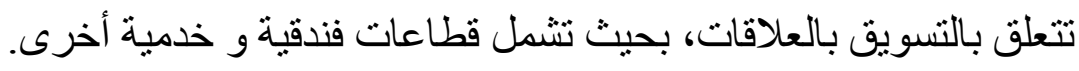

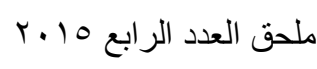

